\title{
O PATRIMÔNIO HISTÓRICO DA EFMM: ENTRE A "POLÍTICA DO PRECÁRIO" E O IMPACTO DA NATUREZA (PORTO VELHO, 2007-2017)
}

EFMM'S HISTORICAL HERITAGE: BETWEEN THE "PRICING POLICY" AND THE IMPACT OF NATURE (PORTO VELHO, 2007-2017)

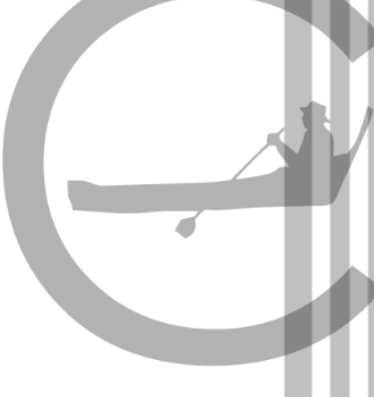

Alexandre Pacheco'

\section{Resumo}

Este trabalho se propõe a realizar uma análise estética e histórica do complexo da Estrada de Ferro Madeira Mamoré - EFMM, na cidade de Porto Velho (RO), a partir de dois eventos: de um lado, os resultados de sua restauração/revitalização a partir do ano de 2007; de outro, o impacto que sofreu da grande enchente do rio Madeira no ano de 2014. A fundamentação teórico-metodológica levará em conta os estudos de Yêdda Pinheiro Borzacov, Francisco Foot Hardman e João Cezar de Castro Rocha sobre essa problemática amazônica. Autores que contribuem para a percepção de como uma política inadequada de preservação e o impacto destrutivo da natureza silenciaram a memória material da Estrada de Ferro Madeira Mamoré nos últimos anos.

Palavras-chave: Madeira Mamoré; Política do precário; Impacto da natureza.

\begin{abstract}
This work aims to carry out an aesthetic and historical analysis of the Madeira Mamore Railway Complex - EFMM, in the city of Porto Velho (RO), based on two events: on the one hand, the results of its restoration / revitalization from the year 2007; on the other, the impact it suffered from the great flood of the Madeira River in 2014. The theoretical and methodological basis will take into account the studies of Yêdda Pinheiro Borzacov, Francisco Foot Hardman and João Cezar de Castro Rocha on this Amazonian matter. Authors who contribute to the perception of how an inadequate preservation policy and the destructive impact of nature have silenced the material memory of the Madeira Mamoré Railway in recent years.
\end{abstract}

Keywords: Madeira Mamoré; Precarious's policy, Nature’s impact.

\footnotetext{
${ }^{1}$ Doutorado em Sociologia pela Universidade Estadual Paulista Júlio de Mesquita Filho (2006) e PósDoutorado pela Universidade de Stanford, Califórnia (2018). Professor Associado III do Departamento de História. E-mail: alexandrepch@unir.br.
} 


\section{Introdução}

Após a desativação da Estrada de Ferro Madeira Mamoré - EFMM, nos anos de 1970, o transcurso de sua história foi marcado por constantes discussões e intervenções do poder público sobre sua restauração ou revitalização. Nas últimas décadas, milhões de reais de foram gastos a título de compensação social para a preservação do complexo dessa ferrovia em Porto Velho, como também da revitalização da vila de Santo Antônio, a partir da instalação das usinas do rio Madeira.

Com relação ao complexo ferroviário da EFMM, as restaurações/revitalizações realizadas pela municipalidade, para fins turísticos entre os anos de 2007 e 2013, trouxeram artificialidade e contribuíram para o apagamento de sua história. Por sua vez, em Santo Antônio observou-se que as reformas impuseram uma série de construções modernas fora do trajeto original da vila e descontextualizadas da história local.

Por ironia do destino, entretanto, grande parte da revitalização do complexo da EFMM foi destruída pela grande enchente do rio Madeira, em 2014. Fenômeno que cobriu toda a extensão da estação e impôs severa deterioração e destruição às locomotivas e vagões de passageiros que não haviam sido restaurados pela política de compensação. Em outras palavras, um cenário caótico que revelou de forma explícita a inadequação e a fragilidade das intervenções da municipalidade sobre o patrimônio da EEFM, pois se desmancharam após o impacto catastrófico da natureza, fazendo com que ocorresse um trágico equilíbrio estético provindo da degradação tanto dos objetos patrimoniais restaurados/revitalizados, como do antigo patrimônio não restaurado.

Dessa maneira, este artigo tem como foco a análise das intervenções inadequadas do poder público sobre a EFMM entre os anos de 2007 a 2017, no âmbito de uma política de preservação que não só destruiu os traços originais dos bens históricos dessa ferrovia, como também se manifestou na contramão das discussões contemporâneas acerca da conservação do chamado patrimônio ferroviário.

Essa política de preservação inadequada será doravante denominada de "política do precário", de acordo com o sentido trabalhado por João Cezar de Castro Rocha, ou seja, uma política de preservação que destrói a origem e ao mesmo tempo despreza e abandona o patrimônio histórico. ${ }^{2} \mathrm{Na}$ sequência da discussão acima, nosso estudo visa demonstrar como os efeitos do impacto ambiental, no âmbito dessa política precária de preservação, aceleraram o processo de apagamento da memória material da ferrovia nos anos em foco.

${ }^{2}$ CASTRO ROCHA, João Cezar. Leituras desauratizadoras: tempos precários, ensaios provisórios. Chapecó: Argos/Editora - UFPE, $1^{\mathrm{a}}$ ed., 2017, p. 32. 


\section{A descaracterização dos bens históricos da EFMM a partir de uma precária política de preservação para o patrimônio de Porto Velho}

De acordo com Yêdda Borzacov, o surgimento da cidade de Porto Velho se relaciona diretamente com a construção da Estrada de Ferro Madeira Mamoré, tendo ocorrido de forma espontânea e desordenada através do incremento das atividades ferroviárias e portuárias dessa companhia por volta de 1910. A partir desse ponto inicial, percebemos que a região recebeu pessoas de diferentes lugares do país, como: “[...] 'seringueiros, excontratistas da empresa, pequenos comerciantes, aventureiros de todos os naipes, prostitutas e, principalmente por moradores de Santo Antônio do Rio Madeira' [...]". ${ }^{3}$ Seus casebres contrastavam com as modernas instalações da ferrovia e foram construídos "[...] fora dos limites do território convencional cedido à empresa Madeira Mamoré Railway Co. Ltda, gerando protestos da empresa que enviava documentos denunciando a invasão para os governos federal, do Amazonas e do Mato Grosso. ${ }^{, 4}$ Em outros termos, dentro do perímetro geográfico definido para a Madeira Mamoré Railway Company Ltda, que se estendia

"[...] 'no sentido oeste/leste, entre o rio Madeira e o limite com o município de Humaitá e no sentido norte/sul, entre a atual rua Tabajara e o bairro Triângulo' foram abertas pela empresa May, Jeckyll \& Randolph, as primeiras ruas com finalidade de instalação dos casarões de pinho-de Riga, provenientes dos Estados Unidos em forma de "Kits", para servir de escritórios, residências para funcionários graduados, operários, restaurante e outros serviços anexos à ferrovia. ${ }^{5}$

Em 1914, no entanto, a aglomeração de pessoas fora do domínio da Madeira Mamoré Railway Co. Ltda era maior que a quantidade de trabalhadores da ferrovia, de forma que os bairros iniciais de Porto Velho já estavam configurados em 1918. Nesse sentido, o “[...] esquema de arruamento efetuado a esmo pelos migrantes, não obedecia às normas de alinhamento, os casebres eram construídos amontoados, resultando no surgimento do centro comercial, em cuja rua principal foram instaladas as casas de maior representatividade [...]". 6 Isto é, com a instalação do município em 1915, foi iniciado um processo de planejamento

\footnotetext{
${ }^{3}$ BORZACOV, Yêdda Pinheiro. Os bairros na história de Porto Velho. Porto Velho: Porto Velho Gráfica \& Comunicação Visual, $1^{\text {a }}$ ed., 2016, p. 17.

${ }^{4}$ A decisão da instalação da ferrovia no território que se tornaria a cidade de Porto Velho pela Madeira Mamoré Railway Co. Ltda, foi causada pela constatação de que o fracasso das tentativas anteriores de construção da ferrovia em Santo Antônio, relacionou-se com o fato dessa localidade ser conhecida como extremamente insalubre, repleta de doenças, ou seja, "[...] 'um antro de podridão, local onde os homens morriam como moscas [...] mesmo dispondo-se de todo o dinheiro do mundo e da metade de sua população seria impossível construir a estrada' [...]". Cf. BORZACOV, Yêdda Pinheiro. Os bairros na história de Porto Velho, p. 17.

${ }^{5}$ BORZACOV, Yêdda Pinheiro. Os bairros na história de Porto Velho, p. 19.

${ }^{6}$ BORZACOV, Yêdda Pinheiro. Os bairros na história de Porto Velho, p. 19.
} 
organizacional que visou a normatização das construções e do traçado da planta cidade, o que fez com que novos nomes e novas ruas surgissem em substituição das existentes anteriormente. ${ }^{7}$ Por sua vez, nos anos de 1940, Porto Velho passou a ser a capital do Território do Guaporé, tempo em que contava com

“[...] '28 ruas, travessas e avenidas, todas se cruzando na quase totalidade em ângulo reto, e quanto ao número de casas, no perímetro urbano havia 400 edificações e outras 250 no perímetro rural' [...]" Sua população cresceu, iniciando-se, então, uma fase de desenvolvimento, intensificada a partir dos anos de 1960 com a inauguração da BR-29, hoje 364." ${ }^{\prime 8}$

Assim, a amostragem desse desenvolvimento da cidade nos leva a discutir algo importante para os fins deste trabalho e que passou a ocorrer a partir dos anos de 1960, isto é, a integração do centro de à paisagem da EFMM que fez com que parte dos elementos históricos da ferrovia deixassem de existir, pois todo o "[...] "progresso" abraçou-os, asfixiando-os, destruindo-os, assim como outras edificações particulares tradicionais." ${ }^{99} \mathrm{O}$ que chama a atenção, no entanto, nesse processo de modernização que depredou e sucateou o patrimônio da ferrovia, é o fato de que ao poder público sempre coube o papel de realizar obras que desfiguraram a estrutura original da EFMM. ${ }^{10}$ Veja-se o caso das intervenções que foram realizadas pela prefeitura de Porto Velho entre os anos de 2007 a 2013.

A partir de 2007, a municipalidade, financiada pelas políticas de compensação do consórcio Santo Antônio Energia - SAE, iniciou uma série de intervenções que restauraram e revitalizaram as seguintes estruturas do complexo ferroviário da EFMM: estação, dois armazéns de carga, oficina mecânica e rotunda. Intervenções que tiveram o objetivo de transformar o espaço ferroviário para fins turísticos. ${ }^{11}$

Quais foram, entretanto, as intenções e os resultados obtidos a partir dessas intervenções?

As palavras de Alencar podem ser elucidativas:

\footnotetext{
${ }^{7}$ BORZACOV, Yêdda Pinheiro. Os bairros na história de Porto Velho, p. 19.

${ }^{8}$ BORZACOV, Yêdda Pinheiro. Os bairros na história de Porto Velho, p. 22.

${ }^{9}$ BORZACOV, Yêdda Pinheiro. Os bairros na história de Porto Velho, p. 92.

${ }^{10}$ BORZACOV, Yêdda Pinheiro. Os bairros na história de Porto Velho, p. 23.

${ }^{11}$ PINHEIRO, José do Amparo; SILVA, José Luis Gomes. Análise do projeto de revitalização do patrimônio histórico e cultural da estrada de ferro Madeira-Mamoré. Caderno Virtual de Turismo. Rio de Janeiro: UFRJ, v. 14, n. 2, 2014. Disponível em: http://www.ivt.coppe.ufrj.br/caderno/index.php/caderno/article/view/840/397. Acesso em: 6 jun. 2020.
} 
A dinâmica social da cidade junto às políticas preservacionistas atrela determinados bens culturais aos interesses econômicos relacionados ao turismo. A valorização do patrimônio cultural através da execução de projetos de revitalização destinados a atender demandas das atividades turísticas tendem a promover a alienação de elementos constitutivos da memória coletiva em detrimento de escolhas mercadológicas, privilegiando o valor econômico. ${ }^{12}$

Dessa forma, coube ao poder público, mais uma vez, promover a alienação da memória coletiva presente no patrimônio, ao hierarquizar o que deveria ser preservado, de um lado; por outro, ao descaracterizar os bens históricos para o projeto de modernização para fins mercadológicos.

Nesse sentido, Borzacov destacou a inadequação das intervenções feitas sobre o patrimônio do complexo ferroviário ao afirmar que os trabalhos nos "[...] Galpões n. 1 e n. 2, plano inclinado (cremalheira) e estação [...] não atenderam os preceitos que regem o resgate do patrimônio histórico. "13

As últimas restaurações (galpões n. 1 e n. 2, plano inclinado e estação) foram abusivas e nefastas. $\mathrm{O}$ prédio onde ficavam sanitários ao lado direito da estação foi demolido, em razão dos técnicos responsáveis pela manutenção do patrimônio histórico material não se aperceberem do seu valor inestimável, e, assim, essas ações rompem o vínculo e a memória do porto velhense em relação à sua origem. ${ }^{14}$

\section{Figura 1: Vista de um dos armazéns da EFMM e de seu jardim contemporâneo deteriorado}

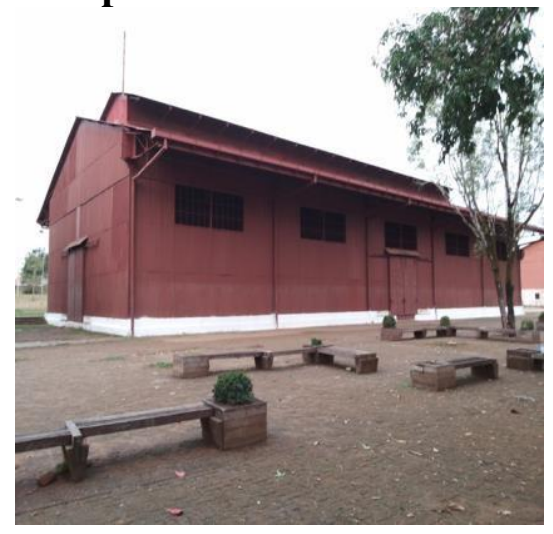

Fonte: Foto do autor, 2017.

12 ALENCAR, Carolina Pena de. Trilhando memórias: reflexões acerca das identidades dos trabalhadores da Estrada de Ferro Madeira-Mamoré. Dissertação de Mestrado, Mestrado Profissional do Instituto do Patrimônio Histórico e Artístico Nacional, Instituto do Patrimônio Histórico e Artístico Nacional, 2012, p. 26.

${ }^{13}$ BORZACOV, Yêdda Pinheiro. Os bairros na história de Porto Velho, p. 91.

${ }^{14}$ BORZACOV, Yêdda Pinheiro. Os bairros na história de Porto Velho, p. 23. 
À degradação ideológica e física promovida pela restauração/revitalização sobre os equipamentos originais da EFMM - que criou um ambiente frio, árido, "um não lugar"15 somou-se, à destruição produzida pelo impacto da grande cheia do rio Madeira, isto em 2014. O resultado foi a emergência de um espaço instável estruturalmente, destruído, deteriorado e que impiedosamente desnudou a ausência de autenticidade, de origem para as formas produzidas pela restauração/revitalização sobre o patrimônio original.

Essa espécie de "disfunção histórica" imposta aos bens patrimoniais da EFMM pelo poder público também pode ser notada em outros espaços restaurados/revitalizados no centro de Porto Velho, como por exemplo, o antigo Mercado Público Municipal. Edificação que teve suas partes antigas demolidas para o advento de uma nova construção, ou seja, um simulacro do antigo mercado: "Em 2008, a municipalidade derrubou os remanescentes - os três boxes e edificou no local, o Mercado Cultural, inaugurado em 15 de maio de 2009 [...]. Mesmo sendo uma pálida amostra do Mercado Público Municipal, “sem nenhum valor histórico", como Alberto Bertagna assim se expressou [...]". ${ }^{16}$

\section{Figura 2: Vista do Mercado Municipal totalmente reconstruído no centro de Porto Velho}

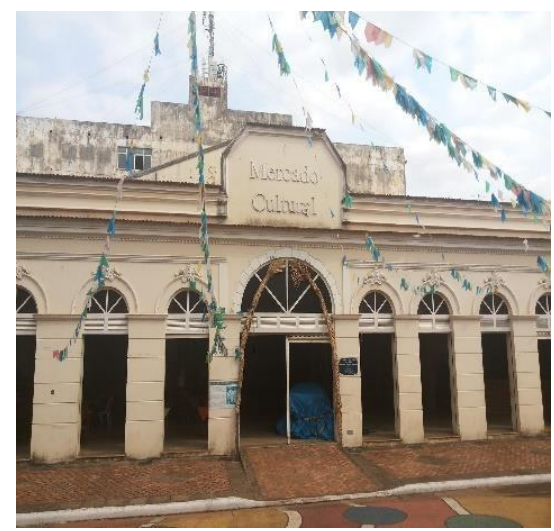

Fonte: Foto do autor, 2017.

Semelhante padrão de restauração/revitalização impõe "disfunção histórica" sobre os bens patrimoniais, adotado também - a título de compensação social por parte da Santo Antônio Energia/SAE - na vila de Santo Antonio. Comunidade que fica a 7 quilômetros de Porto Velho, a montante do rio Madeira, e abrigou as primeiras tentativas de construção da Madeira Mamoré no século XIX. ${ }^{17}$

\footnotetext{
${ }^{15}$ CARDOSO, Ciro Flamarion. Um historiador fala de teoria e metodologia. Bauru: Edusc, $1^{\text {a }}$.ed. 2005, p. 44.

${ }^{16}$ BORZACOV, Yêdda Pinheiro. Os bairros na história de Porto Velho, p. 99.

${ }^{17}$ TEIXEIRA, Marco Antônio Domingues; FONSECA, Dante Ribeiro da. História Regional de Rondônia. Porto Velho: Rondoniana, $4^{\text {a }}$ ed. 2003, p. 178.
} 
Em 1907, já como um pequeno povoado que concentrava alguns produtores de borracha do Alto Madeira, é observado que ele foi escolhido pela empresa construtora May, Jekyll \& Randolph para o início dos trabalhos de construção da Madeira Mamoré Railway. No entanto, um acordo entre essa companhia e o governo estabeleceu que o ponto inicial da construção da ferrovia seria no chamado Ponto Velho, posteriormente denominado Porto Velho. ${ }^{18}$

No caso da Vila de Santo Antônio, a restauração/revitalização fez surgir uma série de construções modernas para servirem as seguintes funções: apoio ao turista, museu, biblioteca, café, entre outras. Em suma, espaços que foram concebidos sem estabelecer ligações arqueológicas com a antiga configuração do povoado ${ }^{19}$, sendo que logo depois de inaugurados em 2014, passaram a se deteriorar devido a recusa da prefeitura em administrálos. Fato que impôs, mais uma vez, uma condição precária a um patrimônio revitalizado ligado ao poder público local.

Andreia Ravani demonstrou a inadequação desse projeto de intervenção da SAE, a partir das ações precárias e descuidadas que possuíram em termos da prospecção das estruturas, peças e o terreno, ou seja, notas que estariam nas origens do patrimônio arqueológico remanescente de Santo Antonio. ${ }^{20}$

Diante de tanta riqueza arqueológica é possível que os trabalhos realizados no Sitio Vila de Santo Antônio tenham sido meramente uma formalidade das exigências feitas aos empreendimentos hidrelétricos, e que por sua vez, causaram impactos ao Sitio Vila de Santo Antônio e áreas adjacentes. Nas observações para este estudo, ficou claro o descaso com o piso antigo, que deveria ter recebido uma atenção do tamanho da sua importância histórica, outro exemplo é o da igrejinha de Santo Antônio que não recebeu obras de restauração, não há marcações nem musealização das peças e estruturas encontradas até o momento. ${ }^{21}$

\footnotetext{
${ }^{18}$ FERREIRA, Manoel Rodrigues. A ferrovia do diabo. São Paulo: Editora Melhoramentos, 2005, p. 202.

${ }^{19}$ De acordo com Rodrigues, Santo Antônio contava com uma única rua onde passavam os trilhos que ligavam o chamado "porto das canoas" ao "porto dos vapores". As casas ao longo desse caminho - onde eram transportadas pelas de borracha - possuíam, de uma forma geral, paredes barreadas. Cf. FERREIRA, Manoel Rodrigues. $A$ ferrovia do diabo, p. 203.

${ }^{20}$ RAVANI, Andreia Silva Andrade. Arqueologia preventiva e os impactos sobre os bens arqueológicos no sítio Vila de Santo Antônio, área da Igrejinha, Porto Velho, RO. Trabalho de Conclusão de Curso, Departamento de Arqueologia, Universidade Federal de Rondônia, 2017, p. 64-65. Disponível em: $<$ http://www.arqueologia.unir.br/uploads/03144268/TCC\%20ANDREIA\%20RAVANI\%202017.1.pdf $>$. Acesso em: 22 fev. 2020.

${ }^{21}$ RAVANI, Andreia Silva Andrade. Arqueologia preventiva e os impactos sobre os bens arqueológicos no sítio Vila de Santo Antônio, área da Igrejinha, Porto Velho, RO, p. 65.
} 
Dessa forma, além do descuido com estruturas, com as peças, com o terreno, o projeto de revitalização impôs a construção de um complexo cultural para visitação totalmente descontextualizado do sítio arqueológico local e suas relações com a história de Santo Antônio e da EFMM. Nesse contexto, João Cezar de Castro Rocha - ao visitar a revitalização de Santo Antônio em 2015 - percebeu não só o descuido com as origens desse espaço, como também a inadequação e a precariedade das formas estéticas que foram impostas pela intervenção sobre o patrimônio e sítio arqueológico desse local:

Seguindo a trilha da Madeira-Mamoré, chegamos ao Sítio Arqueológico Vila de Santo Antônio. A fotografia que você encontrou na capa deste livro foi tirada no seu estacionamento: "Entrada" de ponta-cabeça, metonímia da precariedade sem mais, tal qual, pura e dura. O Sítio Arqueológico é um complexo cultural no qual se destacam a Capela de Santo Antônio de Pádua, um Centro Cultural Indígena e o Marco Divisório dos estados de Amazonas e Mato Grosso. Comecemos pela fronteira anacrônica. A irregularidade da vegetação a seu redor esclarece de imediato o abandono em que se encontra o complexo cultural. O tempo encarregou-se de reduzir a geografia humana a proporções modestas. Em uma década apenas, a aparência é de uma ruína secular, propriamente arqueológica. O marco ainda assim encontra-se ilhado por uma quase-cerca, ou seja, algumas vigas de madeira reunidas ao acaso, todas mal encaixilhadas e de diferente tamanho, literalmente escoradas umas nas outras, num equilíbrio frágil que consterna mais do que protege. Ao lado, uma árvore hesitante também é escorada por materiais os mais diversos: varas de bambu, restos de madeira, um ou talvez dois fios de arame farpado, numa mescla que torna a indiferença, regra. Adiante, um palco improvisado para ocasiões eventualmente festivas oferece como espetáculo uma frágil viga de madeira, tão torta que chega a parecer corcunda, localizada bem no centro do tablado, com a função de sustentar o teto; muito embora esse teto não passe de uma armação sem cobertura. ${ }^{22}$

Assim, as formas que resultaram das restaurações/revitalizações do complexo central da EFMM, do Mercado Cultural e da Vila de Santo Antônio, são representativas de intervenções sobre o patrimônio que, ao invés de preservá-lo, "serve-se dele e o mata aos poucos", já que sempre impõe sobre ele um processo de desauratização. Ou seja, de destruição de suas origens através de uma política de preservação que se transforma em uma "política da escora", uma "política do precário" que suspende as marcas do tempo. Nisso, sem cronologia, sem projeto e, em seguida sua precarização e o abandono. ${ }^{23}$

\footnotetext{
${ }^{22}$ CASTRO ROCHA, João Cezar. Leituras desauratizadoras: tempos precários, ensaios provisórios, p. 30-31.

${ }^{23}$ CASTRO ROCHA, João Cezar. Leituras desauratizadoras: tempos precários, ensaios provisórios, p. 32.
} 
Nesse sentido, as palavras de Castro Rocha sobre esse processo de desauratização que é promovido pela "política da escora" que se transforma em uma "política do precário" sobre os bens patrimoniais:

[...] a política da escora limita-se ao precário, dele não se diferencia, pelo contrário, tende a ele amalgamar-se, como erva daninha que pouco a pouco debilita o tronco da árvore no qual se alimenta. A desauratização, portanto, se refere à ausência de origem, à precariedade a mais acentuada. Essa circunstância produz uma instabilidade estrutural, desautorizando reflexões que não se engajem com esse traço - a falta como primeiro passo do pensamento. ${ }^{24}$

Em julho de 2017, mais um episódio da "política do precário" foi colocado em prática, demonstrando que as intervenções destruidoras do poder público sobre os objetos originais da ferrovia não possuíssem limites. Dessa vez, no entanto, o avanço se deu sobre o "cemitério das locomotivas", espaço que ser formou do encontro da cultura e da natureza nos trilhos da EFMM no bairro Triângulo, uma espécie de Land $\operatorname{Art}^{25}$ que se apresenta de forma inusitada, extraordinária, como efeito colateral da desativação da ferrovia e do abandono de trens ao longo do trajeto entre Porto Velho e Guajará Mirim nos anos de 1970.

Sua beleza provém do poético envolvimento de suas locomotivas enfileiradas em meio à uma vegetação verde escura, às margens do caudaloso rio Madeira, ambiente em que a floresta, os rigores do sol e chuvas amazônicas favorecem a dissolução estrutural delas. Os tons provindos do vermelho ferrugem nos corpos das locomotivas se misturam com os musgos brancos esverdeados, denunciam o avanço da umidade e o lento processo de apodrecimento do aço em seu caminho rumo à natureza. ${ }^{26}$

\footnotetext{
${ }^{24}$ CASTRO ROCHA, João Cezar. Leituras desauratizadoras: tempos precários, ensaios provisórios, p. 32.

${ }^{25} \mathrm{Ou}$ seja, uma arte produzida a partir do pleno desdobramento da beleza das locomotivas em seus processos de retorno à natureza, uma experiência estética engendrada pelo espaço do mundo semelhante à uma espécie de "Land Art". Cf. GUMBRECHT, Hans Ulrich; PACHECO, Alexandre. Vingança da natureza. Suplemento Literário Minas Gerais. Belo Horizonte: Governo do Estado de Minas Gerais, set./out. 2018, n. 1380, p. 14. Tendência artística que se desenvolveu nos Estados Unidos nos anos de 1960 e 1970 e que inovou ao usar os materiais do meio ambiente para criação de obras de arte nas paisagens naturais. Um de seus principais expoentes foi Robert Smithson. Seu trabalho mais conhecido é o Spiral Jetty. Cf. LAND art. Tate. London, 2020. Disponível em: $<$ https://www.tate.org.uk/art/art-terms///land-art>. Acesso em: 28 jul. 2020.

${ }^{26}$ PACHECO, Alexandre; GUMBRECHT, Hans Ulrich. Poética e tragédia nas locomotivas em ruínas do cemitério Ferroviário de Porto Velho, In: Diálogos sobre história, cultura e linguagens. Rio Branco: Nepan, 2019. p. 158. Processo de decomposição inimaginável nos áureos tempos em que as poderosas locomotivas da EFMM rodavam em meio à uma paisagem amazônica pré-histórica. C.f. NOS TRILHOS da Maria louca. Isto é. São Paulo, 02 fev. 2005, n. 2536, p. 1. Disponível em: 〈https://istoe.com.br/98_NOS+TRILHOS+DA+MARIA+LOUCA/> Acesso em 12 mai. 2017.
} 
Pois bem, o governo de Rondônia de forma insensível e violenta retirou uma das locomotivas desse cemitério no mês de julho do ano de 2017, isto é, com o intuito de reformá-la e exibi-la como uma espécie de emblema de civilização em uma praça chamada pela população de Espaço Alternativo.

Veja-se o episódio:

A locomotiva que foi retirada, estava localizada em uma área de tombamento histórico e protegida por lei federal através da Portaria do Iphan 231/2007 e que se encontrava no $\mathrm{Km} \mathrm{2,} \mathrm{do} \mathrm{sítio} \mathrm{Candelária} \mathrm{da}$ EFMM. [...]

Com isso, não havia autorização do Iphan para o DER em fazer a retirada dessa locomotiva até o Espaço Alternativo.

[...] Já o arquiteto Luiz Leite de Oliveira, presidente do Conselho de Administração da Associação de Preservação do Patrimônio Histórico e Amigos da Associação de Preservação do Patrimônio, um acirrado defensor do tombamento pediu posicionamento dos Ministérios Públicos Estadual e Federal e se posicionou a respeito e disse que a situação é crítica. "Uma sucessão de desmazelos e crimes de lesa-pátria contra o patrimônio da mais lendária ferrovia do mundo no século passado. Não pensei que tivessem essa coragem", lamentou. ${ }^{27}$

\section{Figura 3: Espaço aberto após retirada de uma locomotiva pelo DER no} cemitério de trens do bairro do Triângulo

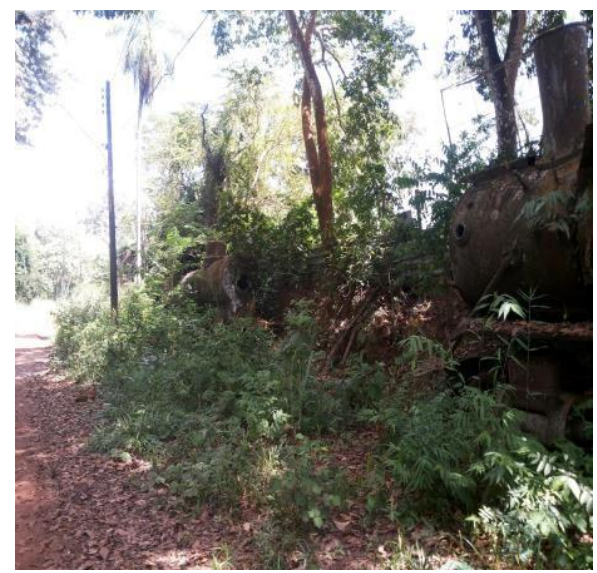

Fonte: Foto do autor, 2018

Dessa forma, o poder público - agora através do governo estadual - reiterou ser o maior inimigo da preservação do patrimônio por revelar sua total ignorância sobre o

\footnotetext{
${ }^{27}$ CONFUSÃO: Locomotiva que foi para o Espaço Alternativo era a errada. O Rondoniense. Porto Velho, 2017. Disponível em: <http://www.orondoniense.com.br/noticias/confusao-locomotiva-que-foi-para-o-espacoalternativo-era-a-errada,8503.shtml > Acesso em: 15 abr. 2018.
} 
significado de um bem pertencente à uma área de tombamento, de um lado; de outro, por impor uma destruição estética irreversível da paisagem histórica das locomotivas em ruínas. Essas que deveriam ficar intocadas para que sempre revelem a trágica forma como foi conduzida pela sociedade local a desativação da ferrovia.

O governo estadual, no entanto, foi obrigado pelo Ministério Público Federal a devolver a locomotiva no mesmo mês de julho de 2017 ao patrimônio da EFMM, fazendoo, no entanto, para o lugar errado, ou seja, para o pátio do complexo da EFMM no centro de Porto Velho. ${ }^{28}$

Apesar dessa sucessão de desastres sobre a ferrovia, o governo de Rondônia novamente deslocou partes de alguns trens do complexo da EFMM para a praça "Espaço Alternativo" em agosto de $2017 .^{29}$

A união das partes dos trens que foram retirados da Madeira Mamoré resultou então na montagem de uma locomotiva que não possui qualquer valor histórico e passou a ser exposta no chamado "Espaço Alternativo" no final de 2017. Episódio que novamente demonstrou a impossibilidade de o poder público agir em prol de uma política de preservação voltada à convivência entre o moderno e a manutenção do antigo. Assim, percebemos que se expressou Sá sobre a locomotiva exposta no "Espaço Alternativo":

Dessa forma, à falta de preservação soma-se não só o impacto das intervenções inadequadas, como também o que Walter Benjamin afirmou ser o advento da barbárie advinda da pobreza de experiência com o passado. ${ }^{30}$

[...] nossa pobreza de experiência é apenas uma parte da grande pobreza que recebeu novamente um rosto, nítido e preciso como o do mendigo medieval. Pois qual o valor de todo o nosso patrimônio cultural, se a experiência não mais o vincula a nós? A horrível mixórdia de estilos e concepções do mundo do século passado mostrou-nos com tanta clareza aonde esses valores culturais podem nos conduzir, quando a experiência nos é subtraída, hipócrita ou sorrateiramente, que é hoje em dia uma prova de honradez confessar nossa pobreza. Sim, é preferível confessar que essa

${ }^{28}$ CASTELO BRANCO, Daniela. IPHAN explica polêmica gerada com locomotiva. Diário da Amazônia. Porto Velho, 2017. Disponível em: <https://www.diariodaamazonia.com.br/iphan-explica-polemica-gerada-comlocomotiva/>. Acesso em: 24 mar. 2020.

${ }^{29}$ CRUZ, Montezuma. Outra locomotiva foi parar no espaço alternativo. Gente de opinião. Porto Velho, 2017. Disponível em: < https://www.gentedeopiniao.com.br/colunista/montezuma-cruz/outra-locomotiva-foi-parar-noespaco-alternativo-por-montezuma-cruz $>$. Acesso em: 04 mar. 2020.

${ }^{30}$ MARTINS, Sandra. A experiência da modernidade e o patrimônio cultural. Reia - Revista de Estudos e Investigações Antropológicas. Recife: PPGA-UFPE, 2014 vol. 1, n. 1, p. 18-19. Disponível em: $<$ https://periodicos.ufpe.br/revistas/reia/article/view/229950/24142> Acesso em: 20 ago. 2019. 
pobreza de experiência não é mais privada, mas de toda a humanidade. Surge assim uma nova barbárie. ${ }^{31}$

Barbárie observada no brutal deslocamento da locomotiva do sítio arqueológico da Candelária, mas também na depredação dos objetos históricos da EFMM ao longo dos trilhos entre Porto Velho e Santo Antônio.

\section{A insistência do poder público na reprodução da "política do precário" para a preservação do patrimônio histórico}

$\mathrm{Na}$ gestão do prefeito Roberto Sobrinho (2005-2012), é observado que as intervenções realizadas em seu governo para a preservação da EFMM e do Mercado Público Municipal giraram em torno da ideia de que esses bens históricos "legitimam e preservam a memória da história de Porto Velho e garantem aos seus munícipes o sentimento de pertencimento." 32

Diante desse cenário, de acordo com Nogueira e Nunes, a prefeitura apresentou um projeto de restauração que foi aprovado pelo IPHAN após serem realizados uma série de ajustes:

Uma das grandes dificuldades para se conseguir recursos para a restauração da Estrada de Ferro, é o fato de que muita gente dizia que ia restaurar, mas não apresentava projetos. Nós apresentamos um projeto aprovado pelo Iphan. Foram feitos todos os ajustes sugeridos pelo instituto e hoje temos a grata satisfação de iniciar esta obra tão importante para a preservação da nossa história, enfatizou Roberto Sobrinho. ${ }^{33}$

No entanto, o que foi posto em prática pela prefeitura foi, na verdade, um projeto de revitalização:

Mediante o quadro de ausências evidenciados na cidade de Porto Velho é inevitável constatar que o que foi alterado, na gestão do ex-prefeito Roberto Sobrinho, foi simplesmente revitalizado. Em se tratando de Estrada de Ferro Madeira-Mamoré [...] de restauração nada foi evidenciado, tendo em vista que os procedimentos ditados e já bastante

\footnotetext{
${ }^{31}$ BENJAMIN,1985b, p 115 apud MARTINS, Sandra. A experiência da modernidade e o patrimônio cultural, $\mathrm{p}$. 18-19. Nesse sentido, não é surpresa saber que até certos membros pertencentes à associação de preservação do patrimônio contribuam para a sua destruição nesse ambiente que insiste em impor modernizações ao patrimônio que nunca se completam. C.f.: Triste fim: peças abandonadas da Madeira Mamoré são vendidas como sucata. Rondoniaovivo. Porto Velho, 2020. Disponível em: <http://rondoniaovivo.com/geral/noticia/2020/01/25/tristefim-pecas-abandonadas-da-madeira-mamore-sao-vendidas-como-sucata.html > . Acesso em 30 mar. 2020.

${ }^{32}$ NOGUEIRA, Mara Genecy Centeno; NUNES, Adriana Cristina da Silva. Restauração ou revitalização? Pontos para repensar o patrimônio público de Porto Velho. In: Simpósio Nacional de História, 27, 2013, Natal. Anais. Natal: UFRN, 2013, p. 2. Disponível em: <https://www.anpuh.org.br/index.php/documentos/anais/categoryitems/1-anais-simposios-anpuh/33-snh27 >. Acesso em: 20 fev. 2020

${ }^{33}$ NOGUEIRA, Mara Genecy Centeno; NUNES, Adriana Cristina da Silva. Restauração ou revitalização? Pontos para repensar o patrimônio público de Porto Velho, p. 2.
} 
difundido pela Arqueologia Histórica, pela Arqueologia Urbana e pelos estudos da Arqueologia da Arquitetura não foram seguidos. ${ }^{34}$

Nogueira e Nunes também observam algo extremamente relevante para nossa discussão: o quase total desconhecimento por parte dos agentes públicos dos estudos e dos instrumentos normativos sobre a preservação do patrimônio histórico edificado no Brasil. Nesse sentido, o desprezo pelos bens patrimoniais demonstrado por governantes também se relaciona com os custos para a restauração e manutenção deles. ${ }^{35} \mathrm{E}$ é por isso que, de uma forma geral, os gestores optam por colocar em prática projetos que realizam sobre as edificações [...] alterações em suas bases arquitetônicas para impor um visual modernizante com o intuito de revitalizar e garantir fontes de recursos aos municípios onde os projetos de revitalização são aplicados. ${ }^{36}$

Para os gestores deve prevalecer o valor de uso sobre a edificação histórica, opção que renega o valor simbólico dos bens patrimoniais e sua significação para a construção de uma relação de identidade com a população que deve conviver com ele. ${ }^{37}$

\begin{abstract}
Afinal, qualquer bem só é patrimônio em decorrência da sua importância simbólica para a sociedade que o elegeu. Ao tentar garantir lucro, o estado ou município que detém a tutela sobre o bem patrimonial e acabam atribuindo outras funções e retirando após a restauração, os atributos que o fizeram ser enaltecido pela sociedade que o elegeu. ${ }^{38}$
\end{abstract}

Dessa forma, as intervenções do poder público não cessaram de descaracterizar ou degradar o patrimônio histórico de Porto Velho nas últimas duas décadas, pois foram guiadas pelo alienado senso comum que exerce sua paixão pelo palpável e que não permite às coisas serem o que elas realmente são. ${ }^{39}$ Exemplo disso foi a revitalização do Mercado Público Municipal, onde as partes remanescentes desse antigo mercado foram demolidas para a construção do chamado "Mercado Cultural". Processo de revitalização que ignorou a importância das ruínas do antigo Mercado, como evidência do trágico incêndio que destruiu

\footnotetext{
${ }^{34}$ NOGUEIRA, Mara Genecy Centeno; NUNES, Adriana Cristina da Silva. Restauração ou revitalização? Pontos para repensar o patrimônio público de Porto Velho, p. 11.

${ }^{35}$ NOGUEIRA, Mara Genecy Centeno; NUNES, Adriana Cristina da Silva. Restauração ou revitalização? Pontos para repensar o patrimônio público de Porto Velho, p. 7-8.

${ }^{36}$ NOGUEIRA, Mara Genecy Centeno; NUNES, Adriana Cristina da Silva. Restauração ou revitalização? Pontos para repensar o patrimônio público de Porto Velho, p. 7.

${ }^{37}$ NOGUEIRA, Mara Genecy Centeno; NUNES, Adriana Cristina da Silva. Restauração ou revitalização? Pontos para repensar o patrimônio público de Porto Velho, p. 9.

${ }^{38}$ NOGUEIRA, Mara Genecy Centeno; NUNES, Adriana Cristina da Silva. Restauração ou revitalização? Pontos para repensar o patrimônio público de Porto Velho, p. 9.

${ }^{39}$ ADORNO, Theodor. Teoria estética. Lisboa: Edições 70, 1970, p. 28.
} 
esse bem cultural, ou seja, uma evidência que poderia evocar o binômio "trauma e memória" para a sociedade local. ${ }^{40}$

Dessa forma, tal arruinamento poderia revelar em termos documentais

[...] valiosos detalhes arquitetônicos até então ocultos, como materiais de construção sob as superfícies de revestimento, composição das fundações, etc., informações fundamentais para aprofundar o conhecimento do bem e subsidiar futuras ações para sua preservação. [...] essas ruínas documentam o episódio trágico que as acometeu, sendo o resultado concreto da destruição. ${ }^{41}$

Dessa forma, convém a seguinte pergunta: por que diante da constante destruição do patrimônio histórico continua a "política do precário" a ser adotada como forma de preservação em Porto Velho?

A resposta a essa pergunta liga-se às posturas voluntaristas, personalistas e até patrimonialistas dos agentes públicos, já que historicamente suas ações de preservação visam antes responder aos anseios de consumo e recreação da população em geral, do que promover ações impessoais guiadas pelas normas de preservação existentes nos estudos acadêmicos sobre os bens patrimoniais. Daí a necessidade de sempre impor o valor de uso sobre eles.

Destarte, tais posturas voluntaristas/personalistas - resultado de uma prevalecente cultura da cordialidade na sociedade brasileira $-{ }^{42}$, institucionalizaram ao longo dos anos o que chamamos de "política do precário" sobre o patrimônio - seja na esfera municipal, estadual ou mesmo federal - como pudemos ver nos exemplos de restauração/revitalização da EFMM, do Mercado Público Municipal e na Vila de Santo Antônio.

\footnotetext{
${ }^{40}$ RODRIGUES, Angela Rosch. Ruína e patrimônio arquitetônico no Brasil: memória e esquecimento. V!rus. São

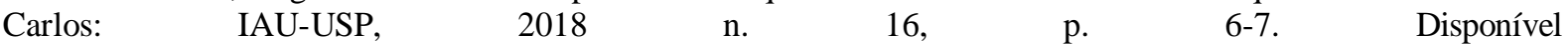
em: $<$ http://www.nomads.usp.br/virus/virus16/secs/submitted/virus_16_submitted_3_pt.pdf $>$. Acesso em: 16 jul. 2019.

${ }^{41}$ RODRIGUES, Angela Rosch. Ruína e patrimônio arquitetônico no Brasil: memória e esquecimento, p. 6-7.

${ }^{42}$ De acordo com Herton Castiglioni Lopes, a postura dos agentes públicos em administrarem o Estado a partir de seus interesses privados, sempre foi uma constante na história do Brasil. Fato que possui intrínsecas relações com a formação de círculos privados que sempre dominaram a esfera pública. Círculos que historicamente engendraram o chamado homem cordial brasileiro e a influência de seu modo de ser na condução do estamento estatal, a partir do personalismo e do patrimonialismo de seus agentes. Nesse sentido, sua análise das relações entre mentalidade cordial no âmbito do estamento estatal e a perpetuação da corrupção, é elucidativa para o entendimento da reprodução constante de certas práticas - no interior do poder do estado - como a precária política sobre o patrimônio histórico. Cf. LOPES, Herton Castiglioni. A corrupção no estado: Uma análise histórica e institucionalista a partir das contribuições de Raymundo Faoro e Sérgio Buarque de Holanda. Revista Gestão Pública Práticas e Desafios. Recife: UFPE, 2014, v. 5, n. 2, p. 11-12. Disponível em:

$<$ https://periodicos.ufpe.br/revistas/gestaopublica/article/view/1861/0>. Acesso em: 20 mar. 2020.
} 
Por outro lado, a postura desses três poderes possuí intrínsecas relações com o desprezo, de uma forma geral, da sociedade local pelo patrimônio. Sociedade que sempre aceitou passivamente as intervenções inadequadas sobre os bens.

Com efeito, foi observado que a "política do precário", ao não ter legado boas práticas sobre a preservação do patrimônio, também deixou de legar parâmetros estéticos adequados para a sociedade local evitar a constante reprodução dessa política de estado desastrada. Por isso, a estética da degradação presente na EFMM, nos prédios públicos, nos espaços públicos e no patrimônio privado do centro de Porto Velho, ao mesmo tempo que revela, também explica porque a cada nova intervenção sobre o patrimônio, o que ocorre no final das contas, é a perpetuação de um modelo que degrada e destrói os bens antigos. ${ }^{43}$

Não se pode deixar de perceber que as posturas voluntaristas e personalistas dos agentes públicos conduzem à "política do precário", isto é, sempre se alimentaram da praticamente inexistência de normas e leis para a conservação dos bens patrimoniais de Porto Velho. ${ }^{44}$

Nogueira e Nunes, nesse sentido, nos esclarecem que

[...] a ausência de legislação municipal e estadual relativas à preservação e tombamento do patrimônio da cidade de Porto Velho, facilita as mutações ao patrimônio edificado. A falta de uma regulamentação leva na maioria dos casos o gestor a impor as transformações que atendem, sobretudo, os interesses de sua administração e não a coletividade. As transformações impostas à malha urbana acabam por alterar a paisagem e aos poucos vão tentando aniquilar a memória afetiva de seus munícipes mais antigos. ${ }^{45}$

E apesar da Lei Orgânica do Município de Porto Velho estabelecer que cabe à municipalidade a conservação dos bens históricos, por outro lado, inexistem órgãos e são escassos os profissionais que poderiam não só fiscalizar, mas também formular leis e

\footnotetext{
${ }^{43}$ A discussão que Herton Castiglioni Lopes realizou sobre a influência que as instituições e os indivíduos possuem na manutenção de hábitos e comportamentos que se cristalizam na sociedade, lança luzes sobre o entendimento da "política do precário" aqui discutida. Dessa forma, a análise das instituições e dos indivíduos deve levar em consideração o fato de que os agentes sofrem influência institucional (upward causation), mas também influenciam as instituições através dos hábitos e comportamentos que compartilham (downward causation). A “[...] emergência das instituições acontece a partir desse processo, pois quando os hábitos enraízam-se na vida social, criam-se instituições fortes que são difíceis de serem alteradas. A mudança e a inércia institucional vão depender dos hábitos mentais e da sua flexibilidade ou rigidez. Veblen demonstra a dificuldade de mudança, já que os hábitos se formam a partir de um contexto histórico." Cf. LOPES, Herton Castiglioni. Revista Gestão Pública Práticas e Desafios, p. 4-6.

${ }^{44}$ NOGUEIRA, Mara Genecy Centeno; NUNES, Adriana Cristina da Silva. Restauração ou revitalização? Pontos para repensar o patrimônio público de Porto Velho, p. 9-10.

${ }^{45}$ NOGUEIRA, Mara Genecy Centeno; NUNES, Adriana Cristina da Silva. Restauração ou revitalização? Pontos para repensar o patrimônio público de Porto Velho, p. 10.
} 
projetos mais claros e adequados à conservação do patrimônio, de forma "[...] a se chegar perto do ideal de se restaurar sem perder os elementos básicos e os traços originais da arquitetura, por exemplo." 46

Diante desse contexto, não surpreende que as intervenções sobre a EFMM foram conduzidas por uma visão fragmentada de sua significação espacial e funcional no território da cidade de Porto Velho, já que deixou "[...] de fora estruturas e conexões essenciais para compreensão da sua funcionalidade." 47

Necessário se faz afirmar, no entanto, a partir do estudo de Maria Emília Lopes Freire que essa visão fragmentada possuiu íntimas relações com a prática institucional nacional voltada ao tombamento e preservação do chamado patrimônio ferroviário, destacando-se, nesse sentido, a influência da própria visão do Instituto do Patrimônio Histórico e Artístico Nacional - IPHAN sobre essa problemática:

Os exemplos expostos no âmbito da prática institucional nacional, que resultam em interpretações - apressadas e simplistas - são reflexos do entendimento do termo patrimônio ferroviário pelo órgão de preservação Nacional (IPHAN), que assim o apreende: "O Patrimônio Ferroviário Brasileiro engloba bens imóveis e móveis, incluindo locomotivas, vagões, carros de passageiros e outros equipamentos, como guindastes, por exemplo, além de mobiliários, bens integrados como relógios, sinos, telégrafos e acervos documentais" (IPHAN)32 Ressalta, portanto, a dimensão material do bem, compreendido de maneira isolada e estanque, desconsiderando sua estruturação em rede e seu contexto territorial. ${ }^{48}$

Dessa forma, devido à ausência de parâmetros teórico-metodológicos por parte do poder público, foram realizadas escolhas na área de tombamento da EFMM que fragmentaram sua complexidade espacial, e comprometeram a lógica da funcionalidade de sua rede ferroviária, desmantelaram o seu patrimônio, e, por fim, destruíram a sistemicidade $^{49}$ que possuiu com o contexto territorial de Porto Velho.

\footnotetext{
${ }^{46}$ NOGUEIRA, Mara Genecy Centeno; NUNES, Adriana Cristina da Silva. Restauração ou revitalização? Pontos para repensar o patrimônio público de Porto Velho, p. 10-11.

${ }^{47}$ FREIRE, Maria Emília Lopes. Patrimônio ferroviário: por uma compreensão de sua lógica funcional. Dissertação de Mestrado, Desenvolvimento urbano, Centro de Artes e Comunicação, Universidade Federal de Pernambuco, 2015, 2 p. $12 . \quad$ Disponível em: $<$ https://repositorio.ufpe.br/bitstream/123456789/17273/1/Disserta\%C3\%A7\%C3\%A3o\%20de\%20Mestrado_Al una\%20Maria\%20Em\%C3\%ADlia\%20Lopes\%20Freire\%20_Patrim\%C3\%B4nio\%20ferrovi\%C3\%A1rio_por\% 20 uma $\% 20$ compreens $\%$ C3\%A3o\%20sist $\%$ C3\%AAmica\%20da $\% 20$ sua $\% 201 \%$ C3\%B3gi $\sim 1$.pdf $\$$. Acesso em: 29 out. 2020.

${ }^{48}$ FREIRE, Maria Emília Lopes. Patrimônio ferroviário: por uma compreensão de sua lógica funcional, p. 36. ${ }^{49}$ FREIRE, Maria Emília Lopes. Patrimônio ferroviário: por uma compreensão de sua lógica funcional, p. 15.
} 
Na sequência será discutido como o impacto da natureza aprofundou o processo de destruição dos bens patrimoniais da EFMM, ou seja, no âmbito de uma política de conservação que desconsiderou os efeitos ambientais dos grandes empreendimentos.

\section{Os impactos destruidores da natureza sobre o patrimônio histórico de Porto} Velho

A partir de 2007, como demonstramos, o governo municipal iniciou a restauração revitalização do antigo complexo ferroviária da EFMM. Sete anos depois, ou seja, em 2014, uma grande inundação do rio Madeira destruiu grande parte das reformas realizadas, trazendo abandono, o crime, o uso de drogas e a prostituição ao local. Assim, indagamos saber: Quais foram, no entanto, os impactos estéticos da grande cheia do rio Madeira em 2014, sobre o patrimônio restaurado/revitalizado?

O prédio da estação está conservado desde os trabalhos de restauração realizados a partir do ano 2007. As avarias que ele sofreu se relacionam mais à deterioração imposta pela ação climática sobre os arranjos paisagísticos contemporâneos que circundam esse prédio. Arranjos formados por bancos de tábuas de madeira onde existem nas extremidades caixetas com arbustos verdes e flores vermelhas. ${ }^{50}$

Figura 4: Arranjo paisagístico arruinado ao redor da estação da EFMM no complexo

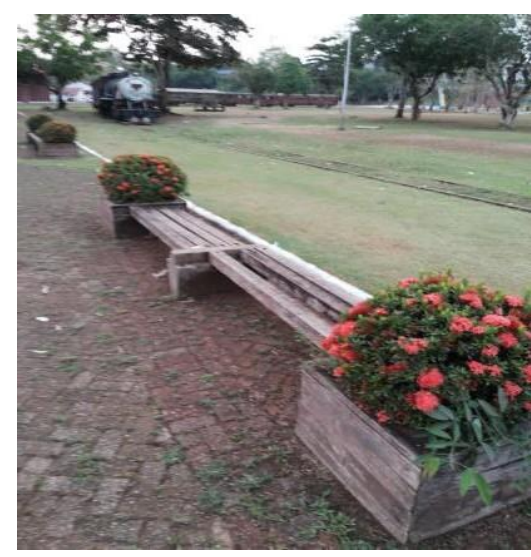

Fonte: Foto do autor, 2017.

Desse modo, percebemos que às margens do rio Madeira, a EFMM possui dois grandes armazéns. Isto é, eles estão bem conservados graças às restaurações iniciadas em

\footnotetext{
50 PACHECO, Alexandre. Restauração, ruínas e experiência estética na estação da Estrada de Ferro Madeira Mamoré em Porto Velho (2007-2017). Patrimônio e História. Assis: CEDAP, 2020, v. 16, n. 1, p. 295. Disponível em: <file://C:/Users/User/Downloads/1046-4223-1-PB\%20(4).pdf>. Acesso em: 28 jul. 2020.
} 
2007. Assim, nas paredes externas desses galpões voltadas para o rio Madeira, surge um deck deteriorado e um calçamento de blocos de cimento que se estende a outro deck destruído. Deck que margeia as grades de proteção nas barrancas do rio Madeira.

Sobre o vasto calçamento de blocos foi erigido o mesmo padrão de paisagismo concebido para o prédio da estação da EFMM. Paisagismo que se encontra castigado pela ação do tempo, pela depredação e que convive com os entulhos de madeira do destruído deck às margens do rio Madeira. A deterioração dos arranjos paisagísticos contemporâneos (assentos e decks) instalados na estação e nos armazéns tornou-se inevitável devido ao uso de madeira, material inadequado ao clima local e de fácil destruição pela depredação. ${ }^{51}$

\section{Figura 5: Vista de um dos galpões da ferrovia com seu deck deteriorado}

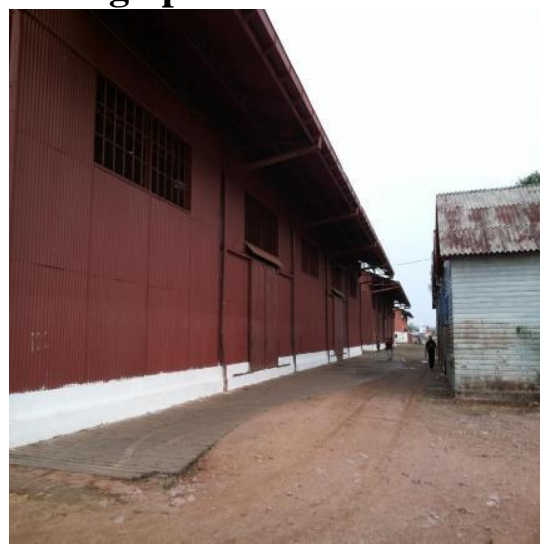

Fonte: Foto do autor, 2017

Figura 6: Deck destruído pela enchente do rio Madeira

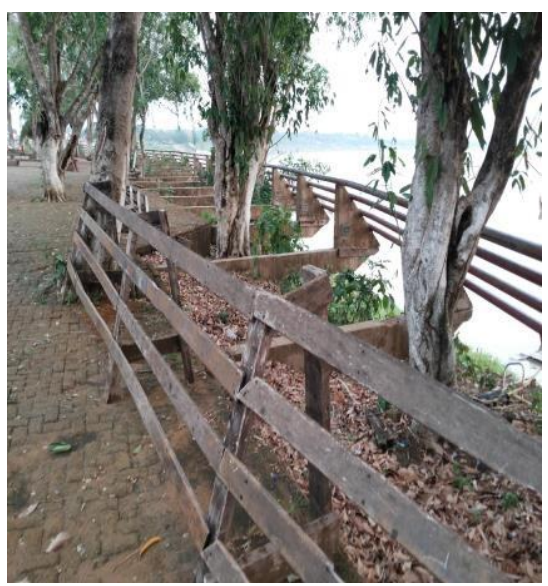

Fonte: Foto do autor, 2017.

\footnotetext{
${ }^{51} \mathrm{PACHECO}$, Alexandre. Restauração, ruínas e experiência estética na estação da Estrada de Ferro Madeira
} Mamoré em Porto Velho (2007-2017), p. 295. 
O término da restauração da oficina da EFMM se deu em $2013^{52}$. No seu entorno temos locomotivas e vagões em decomposição, ruínas da antiga casa de força, entulhos de velhos materiais da ferrovia, lixo, mato, grades destruídas. Um prédio que foi também abandonado pela municipalidade e tornou-se local de consumo de drogas, prostituição e assaltos.

Tais condições formam uma paisagem desestabilizadora das pretensões estéticas produzidas pelas obras de restauração/revitalização nas outras partes da estação. Essa desestabilização, no entanto, é atenuada pelo fato de que a mesma ação climática, o abandono e a depredação que provocaram a formação de ruínas no entorno da oficina, também avançam sobre os prédios restaurados, sobretudo nos arranjos paisagísticos contemporâneos que cercam eles, como já expomos acima. Mas a situação de deterioração se manifesta principalmente nas grades de ferro e nas calçadas que margeiam a EFMM com a Avenida Farquhar. Na seção onde se encontram os quiosques, na citada avenida, as grades e os bancos que simulam um estilo belle époque estão em estado de ruínas. ${ }^{53}$

Somada à destruição dessas áreas restauradas/revitalizadas ocorreu também a aceleração da decomposição e da destruição de locomotivas e de vários vagões de passageiros que estavam estacionados na praça da EFMM.

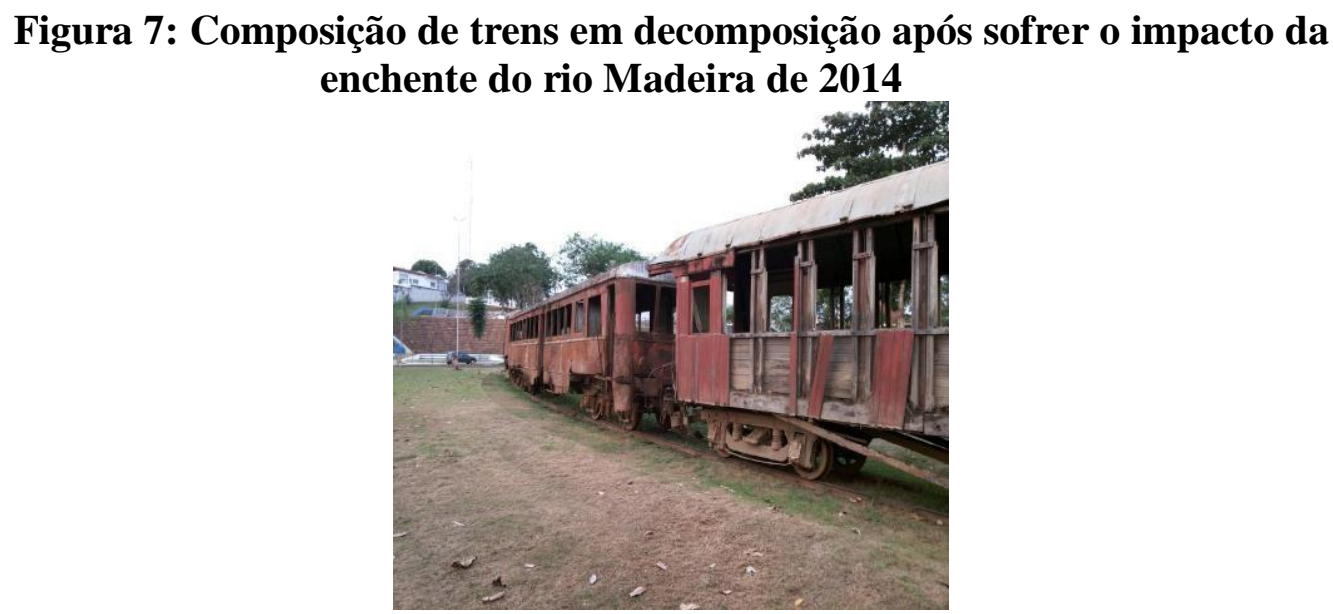

Fonte: Foto do autor. 2017.

A catastrófica enchente do rio Madeira acelerou a decomposição do patrimônio da EFMM e suspendeu radicalmente o resultado estético da restauração e da revitalização

52 RESTAURAÇÃO do galpão da Madeira-Mamoré está na fase final. G1 RO. Porto Velho, 2 ago. 2013. Disponível em: <http://g1.globo.com/ro/rondonia/noticia/2013/08/restauracao-do-galpao-da-madeira-mamoreesta-na-fase-final-em-ro.html>. Acesso em: 6 jun. 2020.

${ }^{53}$ PACHECO, Alexandre. Restauração, ruínas e experiência estética na estação da Estrada de Ferro Madeira Mamoré em Porto Velho (2007-2017), p. 298. 
realizados a partir de 2007. Intervenções, enfim, que tiveram o objetivo de criar um ambiente para o turismo naquele espaço histórico.

\title{
Os impactos da natureza sobre o patrimônio da EFMM no bairro Triângulo
}

A atmosfera histórica do tradicional bairro Triângulo, apesar de toda a destruição causada pelas enchentes, ainda lembra os tempos em que as locomotivas percorriam os trilhos às margens do rio Madeira. Ao longo desse trajeto, de acordo com a descrição romântica de Borzacov, os antigos moradores, gente de convivência amistosa, escutavam “o resfolegar e os apitos das locomotivas e os ruídos dos vagões, sentindo o cheiro característico de madeira advindo da serraria Tiradentes".

Era o bairro dos antigos ferroviários, local em que a presença da EFMM se mesclava às saudosas memórias de um mundo não mais existente, mas constantemente revividas, de acordo com Borzacov, em versos como "Exaltação do Triângulo", do poeta popular Ernesto de Melo:

\begin{abstract}
Já me falou o poeta/ que o teu passado foi glória/ vou recordar tua história/ daqueles tempos p'ra cá/ depois que o tempo da boemia passou/ o $5^{\circ} \mathrm{BEC}$ chegou trazendo os seus generais/ a força do poder da ditadura/ não respeitou minha cultura/ destruiu meus ideais/ Morro do Querosene veio abaixo/ o Alto do Bode hoje é baixo/ e nem tem Baixa do União/ Madeira Mamoré só por pirraça/ calou a Maria Fumaça ferindo o meu coração/ se o tempo da boemia passou/ quero que passe o tempo dos generais/ Triângulo, Triângulo/ quem te viu naquele tempo não reconhece jamais/ hoje tem até desmoronamento/ tem enchentes que tiram o teu povo de lá/ quem me dera resgatar minha bandeira/ pela Vila Cachoeira/ e tirar o progresso de lá. ${ }^{54}$
\end{abstract}

Por outro lado, essa atmosfera de ligação do Triângulo com a história da EFMM seria profundamente afetada a partir do ano de 2012, com o início do funcionamento da Usina de Santo Antônio.

Em 23 de janeiro de 2012 as comportas da Usina Hidrelétrica de Santo Antônio foram abertas, ocasionando o desbarrancamento de cerca de $7 \mathrm{~km}$ à jusante do eixo da barragem, afetando diretamente o Bairro Triângulo. Mais de cem moradias foram atingidas pela erosão, sendo necessário um processo de remanejamento emergencial destes moradores, os quais foram levados para hotéis e pousadas da capital. ${ }^{55}$

\footnotetext{
${ }^{54}$ BORZACOV, Yêdda Pinheiro. Os bairros na história de Porto Velho, p. 268-269.

${ }^{55}$ SANTOS, Felipe Pinheiro dos; ARAÚJO, Rayanne Cristina; AGUIAR, Sandra Garcia; BARBA, Clarides Henrich de. Impactos sócio-econômicos das hidrelétricas do Madeira: um estudo no bairro Triângulo em Porto Velho/RO. In: Congresso Nacional de excelência em gestão, 10, 2014, Rio de Janeiro. Anais. Rio de Janeiro: UFF,
} 


\section{Figura 8: Vista da área da região desbarrancada próxima ao cemitério das} locomotivas e do cemitério da Candelária no bairro Triângulo

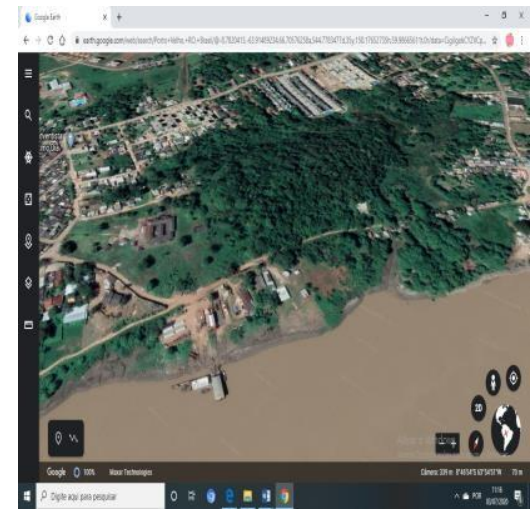

Fonte: Google Earth, 2020.

Dessa forma, a grande enchente do Rio Madeira, em 2014, acelerou os impactos ambientais sobre o antigo bairro, consolidando a destruição quase que total de suas habitações tradicionais e da paisagem bucólica que existia no transcurso dos trilhos da EFMM às margens do rio Madeira. Esse impacto ambiental não só acelerou a destruição dos trilhos das locomotivas estacionadas no "cemitério dos trens", como também das edificações do cemitério da Candelária, mas isto contribuiu para a depredação de todo esse patrimônio ao provocar o despovoamento, o abandono e o aumento da violência na orla do Triângulo no rio Madeira. A partir disso, formou-se um círculo vicioso entre o impacto ambiental e o aprofundamento da depredação da EFMM, considerando o trajeto desde o [...] (pátio ferroviário, $8 \mathrm{~km}$ de trecho férreo compreendidos entre Porto Velho/Santo Antônio, o Cemitério da Candelária e as três Caixas D'Água), protegidas por legislação do Instituto do Patrimônio Histórico e Artístico Nacional - IPHAN, constantemente agredido e destruído. ${ }^{56}$

Figura 9 - Locomotiva abandonada e depredada no bairro Triângulo

2014, p. 15-16. Disponível em: <https://www.inovarse.org/sites/default/files/T14_0251_3.pdf >. Acesso em: 20 abr. 2020.

${ }^{56}$ BORZACOV, Yêdda Pinheiro. Os bairros na história de Porto Velho, p. 23. 


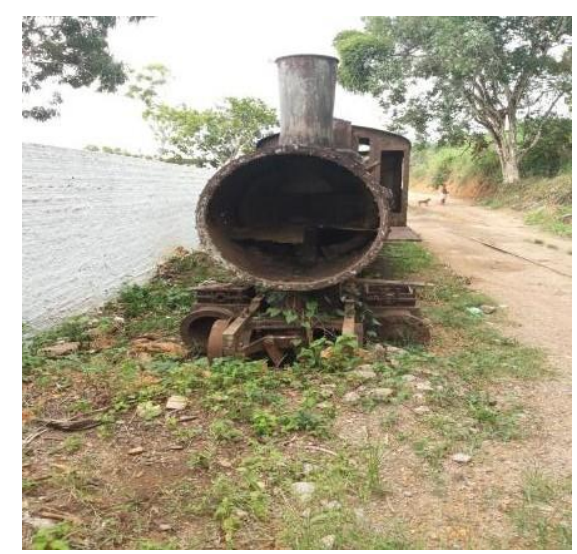

Fonte: Foto de João Cezar de Castro Rocha, 2015.

Mas como pode ser pensado esse impacto da natureza sobre o patrimônio daEFMM no âmbito da uma política de conservação que não realizou estudos sobre os efeitos ambientais sobre a área de tombamento histórico da EFMM?

\section{A política do precário diante do impacto ambiental sobre o patrimônio da}

\section{EFMM}

Em primeiro lugar, é preciso se ater ao fato de que no período da restauração/revitalização do complexo da EFMM, entre os anos de 2007 a 2013, inexistiam tanto ao nível local, como ao nível nacional, instrumentos legais e com critérios específicos para avaliação do impacto ambiental dos grandes empreendimentos sobre o patrimônio material e imaterial. ${ }^{57}$ Nesse sentido, a concessão do chamado "Licenciamento Cultural" muito tardiamente - começou a ser realizada por órgãos como o IPHAN:

[...] o Iphan até muito recentemente não possuía um instrumento legal que estabelecesse os critérios de avaliação definidos para seu procedimento de análise quanto à concessão de anuência ao licenciamento ambiental. E ainda, até meados de 2009, o então denominado "Licenciamento Cultural", analisava os impactos dos empreendimentos e se pronunciava somenteem relação ao patrimônio arqueológico.

A partir do ano de 2009 é que a instituição passou a se debruçar acerca dos impactos às referências culturais de natureza material e imaterial, como um todo, nas áreas de influência dos empreendimentos, propondo medidas que os impedissem ou minimizassem através de Termos de Referência [... ${ }^{58}$

\footnotetext{
${ }^{57}$ BONFIM, Paôla Manfredini Romão; HENKES, Jairo Afonso; GUIMARÃES, Geovan Martins. Revista gestão e sustentabilidade ambiental. Florianópolis, UNISUL, out/dez. 2019, v. 8, n. 4, p. 11. Disponível em:

$<$ http://www.portaldeperiodicos.unisul.br/index.php/gestao_ambiental/article/view/8565/4767>. Acesso em: 26 out. 2020.

${ }^{58}$ BONFIM, Paôla Manfredini Romão; HENKES, Jairo Afonso; GUIMARÃES, Geovan Martins. Revista gestão e sustentabilidade ambiental. p. 11.
} 
No entanto, somente a partir do ano de 2015, no período posterior às intervenções que ora discutimos neste artigo, é que o IPHAN viria a estabelecer um conjunto de regras para o chamado "Licenciamento Cultural":

[...] primeiramente com a Portaria Interministerial $\mathrm{n}^{\circ} 60$, de 24 de março de 2015, que regulamenta a atuação dos órgãos e entidades da Administração Pública Federal envolvidos no licenciamento ambiental federal e disciplina os estudos necessários para a identificação de impactos ao patrimônio cultural causados por empreendimentos que excedem os limites estaduais, e são, portanto, licenciados pelo Ibama.

E, logo em seguida pela Instrução Normativa $\mathrm{n}^{\circ}$ 001, de 25 de março de 2015, que estabelece procedimentos administrativos a serem observados pela Autarquia nos processos de licenciamento ambiental dos quais participe. E posteriormente, a Portaria Iphan $n^{\circ}$ 199/2016, que cria a Coordenação Técnica Nacional de Licenciamento no Iphan, substituindo a Coordenação anterior de 2012. ${ }^{59}$

Nesse sentido, diante de um contexto em que inexistiam regras para a concessão do chamado "Licenciamento Cultural”, o que poderia ter sido feito por uma precária política de preservação para atenuar os impactos que os grandes empreendimentos impuseram à EFMM? A resposta seria: pouco ou quase nada.

Como demonstrado acima, grande parte dos bens históricos da EFMM, tanto no complexo ferroviário, como no bairro Triângulo, foram irreversivelmente deteriorados ou destruídos pelos danos ambientais causados pela enchente do rio Madeira. Portanto, diante dessa trágica constatação sobre o destino do patrimônio da ferrovia em que ações de restauro não são mais passíveis de recuperar os traços originais de grande parte dos bens remanescentes, uma percepção diferenciada de preservação deveria ser lançada sobre esses bens, ou seja, a partir das discussões contemporâneas sobre as relações entre ruína e patrimônio.

Nesse cenário, de acordo com Angela Rosch Rodrigues, ainda que as ruínas se constituam uma antítese dos objetivos últimos da preservação, essa autora chama-nos atenção para o fato de que remanescentes arquitetônicos em ruínas do patrimônio nacional, desde os anos de 1930, passaram a ser "[...] identificados enquanto bens culturais na composição do ideário de história e construção da memória nas políticas de preservação dos órgãos de preservação no Brasil. " 60

\footnotetext{
${ }^{59}$ BONFIM, Paôla Manfredini Romão; HENKES, Jairo Afonso; GUIMARÃES, Geovan Martins. Revista gestão e sustentabilidade ambiental, p. 13.

${ }^{60}$ RODRIGUES, Angela Rosch. Ruína e patrimônio arquitetônico no Brasil: memória e esquecimento, p. 1.
} 
No âmbito dessa função histórica e considerando os graus de destruição que Rodrigues categoriza as ruínas, pode-se afirmar que o arruinamento do patrimônio da EFMM se formou a partir de fatores, como: a falta de cuidado, o desleixo, a negligência e a catástrofe natural ou antrópica. Ou seja, ruínas provenientes da incúria ou do incidente. ${ }^{61}$

Dessa forma, considerando que praticamente todo o patrimônio da EFMM que havia sido arruinado pela incúria da municipalidade teve sua deterioração e destruição aprofundados pelo incidente catastrófico da enchente, o seguinte questionamento se faz necessário: quais os tipos de sensações relativas ao passado os objetos históricos arruinados da EFMM poderiam incitar, caso fossem observados, a partir dos parâmetros das discussões contemporâneas, as relações entre ruína e patrimônio?

Entende-se aqui que poderiam provocar sensações semelhantes às discutidas por Rodrigues quando esse afirma, citando Starobinsk, que as ruínas podem evocar sentimentos de perplexidade por incorporarem os trágicos e violentos eventos que as produziram no passado, isto é, de forma que quanto mais recentes forem as ruínas, mais forte serão os sentimentos de desassossego que transmitirão ao observador, já que para “[...] que uma ruína pareça bela é preciso que a destruição seja bastante longínqua [...]. Ninguém sonha tranquilamente diante de ruínas recentes que fazem sentir o massacre: estas são logo desentulhadas para reconstruir" ${ }^{\prime 62}$

As ruínas do incidente podem se tornar símbolos que asseguram o "sentido memorável atribuído a qualquer catástrofe". No Brasil, as ruínas provenientes do rompimento da barragem do Fundão da Samarco Mineração SA em Bento Rodrigues (subdistrito de Mariana, MG) em 2015 amplificam de modo inconteste o papel patrimonial delatando o trágico evento com uma mensagem de penosa sobrevivência. ${ }^{63}$

Assim, uma nova proposta para a conservação do patrimônio da EFMM - que romperia definitivamente com política de conservação improvisada e populista da municipalidade - não mais negaria as ruínas enquanto um patrimônio significativo da ferrovia, pois permitiria a metamorfose dos traços originais dos objetos arruinados em seus respectivos processos de retorno à natureza. ${ }^{64} \mathrm{Em}$ outras palavras, isto significa que a fusão entre cultura e natureza era capaz de exortar sensações de perplexidade, como afirma

\footnotetext{
${ }^{61}$ RODRIGUES, Angela Rosch. Ruína e patrimônio arquitetônico no Brasil: memória e esquecimento, p.2.

${ }^{62}$ STAROBINSKI, 1994, p. 202 apud RODRIGUES, Angela Rosch. Ruína e patrimônio arquitetônico no Brasil: memória e esquecimento, p. 6-7.

${ }^{63}$ RODRIGUES, Angela Rosch. Ruína e patrimônio arquitetônico no Brasil: memória e esquecimento, p. 6.

${ }^{64}$ GUMBRECHT, Hans Ulrich; PACHECO, Alexandre. Vingança da natureza, p. 13-14.
} 
Rodrigues, algo que se configuram esteticamente como "[...] elementos que testemunham a sobrevivência do que existiu, ou seja, a partir delas poderiam ser extraídas informações sobre a composição anterior do objeto, mas também testemunham as causas da destruição e do que pode ser esquecido." 65

Essa nova proposta de intervenção, inclusive, poderia ser pensada para a área de tombamento da EFMM no trecho conhecido como cemitério das locomotivas, no histórico bairro Triângulo, “[...] para a preservação da tensa beleza natural que se formou entre as máquinas ferroviárias e a mata às margens do rio Madeira. Essa proposta também deveria ser estendida à estação central da EFMM na medida em que lá existem vários equipamentos em ruínas. $" 66$

Por outro lado, aceitar os desdobramentos das ruínas da EFMM em seu processo de retorno à natureza, bem como a evocação das experiências estéticas que podem suscitar, como descrito acima, seria também acrescer uma dimensão ecológica à política de preservação da área de tombamento histórico da EFMM, já que seria uma forma de estabelecer uma adaptação dessa área aos rigores climáticos que assolam a região Amazônica.

\section{Considerações finais}

$\mathrm{Na}$ conclusão, pode-se afirmar que as ações restauradoras/revitalizadoras realizadas no complexo ferroviário da EFMM, a partir de 2007, complementaram, no campo da cultura, a continuidade do processo de destruição do patrimônio da ferrovia que se iniciou com os ciclos de modernização a partir dos anos de 1960. Isto significa que as intervenções que simbolicamente impuseram ao patrimônio a ideia de que o passado deve ser disfarçado ou suplantado. Processo silenciador da história da EFMM que tem sido incrementado pelo impacto destrutivo da natureza na região.

Dessa forma, como demonstrado, por um lado, o anseio pelo moderno convive com os traços de arcaísmos peculiares a nossa cultura, sobretudo quando se constata que as posturas personalistas e patrimonialistas dos agentes públicos sempre fomentam soluções que deformam o patrimônio; por outro, os impactos da ação climática concorrem para a decomposição e destruição tanto dos bens degradados pela política inadequada de preservação, quanto do restante patrimônio original da EFMM. Ou seja, os impactos da

\footnotetext{
${ }^{65}$ RODRIGUES, Angela Rosch. Ruína e patrimônio arquitetônico no Brasil: memória e esquecimento, p. 1.

${ }^{66}$ GUMBRECHT, Hans Ulrich; PACHECO, Alexandre. Vingança da natureza, p. 14.
} 
natureza concorrem para uma constante reprodução de um estado estético resultante da decomposição e destruição tanto das formas patrimoniais degradadas, como das formas originais do patrimônio.

Data de submissão: $05 / 08 / 2020$

Data de aceite: 04/11/2020 


\section{Referências bibliográficas}

ADORNO, Theodor. Teoria estética. Lisboa: Edições 70, 1970.

ALENCAR, Carolina Pena de. Trilhando memórias: reflexões acerca das identidades dos trabalhadores da Estrada de Ferro Madeira-Mamoré. 2012. 137 f. Dissertação (Mestrado Profissional do Instituto do Patrimônio Histórico e Artístico Nacional) -Instituto do Patrimônio Histórico e Artístico Nacional, Rio de Janeiro, 2012.

ARAÚJO, Wagner dos Reis Marques. A expansão das fronteiras amazônicas: o legado das Usinas Hidrelétricas (UHEs) Santo Antonio e Jirau no estado de Rondônia (RO). RELEM - Revista Eletrônica Mutações, Manaus, v. 8, n. 15, p. 92-105, jul-dez 2017. Disponível em: https://www.periodicos.ufam.edu.br/index.php/ relem/article/view/3378. Acesso em: 8 jun. 2020.

BONFIM, Paôla Manfredini Romão; HENKES, Jairo Afonso; GUIMARÃES, Geovan Martins. Revista gestão e sustentabilidade ambiental. Florianópolis, UNISUL, out/dez. 2019, v. $8, \quad$ n. $4, \quad$ p. 11.4 Disponível em: $<$ http://www.portaldeperiodicos.unisul.br/index.php/gestao_ambiental/article/view/8565/4 767>. Acesso em: 26 out. 2020.

BORZACOV, Yêdda Pinheiro. Os bairros na história de Porto Velho. Porto Velho: Porto Velho Gráfica \& Comunicação Visual, 2016.

CARDOSO, Ciro Flamarion. Um historiador fala de teoria e metodologia. Bauru: Edusc, $1^{\mathrm{a}}$ ed., 2005.

CASTELO BRANCO, Daniela. IPHAN explica polêmica gerada com locomotiva. Diário da Amazônia, Porto Velho, 2017. Disponível em: $<$ https://www.diariodaamazonia.com.br/iphan-explica-polemica-gerada-com-locomotiva/ $>$. Acesso em: 24 mar. 2020.

CASTRO ROCHA, João Cezar. Leituras desauratizadoras: tempos precários, ensaios provisórios. Chapecó: Argos/Editora - UFPE, 2017.

CONFUSÃO: Locomotiva que foi para o Espaço Alternativo era a errada. O Rondoniense, Porto Velho, 2017. Disponível em: <http://www.orondoniense.com.br/noticias/confusaolocomotiva-que-foi-para-o-espaco-alternativo-era-a-errada,8503.shtml $>$ Acesso em: 15 abr. 2018.

CRUZ, Montezuma. Outra locomotiva foi parar no espaço alternativo. Gente de opinião,

Porto Velho, 2017. Disponível em:

$<$ https://www.gentedeopiniao.com.br/colunista/montezuma-cruz/outra-locomotiva-foiparar-no-espaco-alternativo-por-montezuma-cruz> $>$. Acesso em: 04 mar. 2020.

FERREIRA, Manoel Rodrigues. A ferrovia do diabo. São Paulo: Editora Melhoramentos, 2005.

FERROVIA amazônica é símbolo do abandono. Tudorondonia.com, Porto Velho, 18 set. 2009. Disponível em: https://www.tudorondonia.com/noticias/ferrovia-amazonia-esimbolo-do- abandono. Acesso em: 6 jun. 2020.

FREIRE, Maria Emília Lopes. Patrimônio ferroviário: por uma compreensão de sua lógica funcional. Dissertação de Mestrado, Desenvolvimento urbano, Centro de Artes e Comunicação, Universidade Federal de Pernambuco, 2015, p. 12. Disponível em: $<$ https://repositorio.ufpe.br/bitstream/123456789/17273/1/Disserta\%C3\%A7\%C3\%A3o\%2 
0de\%20Mestrado_Aluna\%20Maria\%20Em\%C3\%ADlia\%20Lopes\%20Freire\%20_Patrim $\%$ C3\%B4nio\%20ferrovi\%C3\%A1rio_por\%20uma\%20compreens\%C3\%A3o\%20sist\%C3 $\%$ AAmica\%20da\%20sua\%201\%C3\%B3gi 1.pdf>. Acesso em: 29 out. 2020.

GOMES, Emmanoel. Madeira Mamoré: cem anos de agonia e desprezo. Rondônia em Pauta, Porto Velho, 30 dez. 2013. Disponível em: http://rondoniaempauta.com.br/nl/historia/ emmanoel/artigo-madeira-mamore-cem-anosde-agonia-e-desprezo/. Acesso em: 6 jun. 2020.

GONÇALVES FILHO, Elmir Marques; ALMEIDA, Fabrício Moraes de; SOUZA, Carlos Henrique Medeiros de. Metamorfose, desenvolvimento regional e os empreendimentos hidrelétricos do rio Madeira - Porto Velho, RO (Brasil). Intersciencieplace, n. 31, p. 144, out.-dez. 2014. Disponível em: http://www.interscienceplace.org/isp/index.php/isp/ article/view/299/296. Acesso em: 10 jun. 2020.

GUMBRECHT, Hans Ulrich; PACHECO, Alexandre. Vingança da natureza. Suplemento Literário Minas Gerais. Belo Horizonte: Governo do Estado de Minas Gerais, n. 1380, set/out. 2018.

LAND art. Tate. London, 2020. Disponível em: <https://www.tate.org.uk/art/artterms/l/land-art>. Acesso em: 28 jul. 2020.

LOPES, Herton Castiglioni. A corrupção no estado: Uma análise histórica e institucionalista a partir das contribuições de Raymundo Faoro e Sérgio Buarque de Holanda. Revista Gestão Pública Práticas e Desafios, Recife, v. 5, n. 2, p. 1-19, 2014. Disponível em: <https://periodicos.ufpe.br/revistas/gestaopublica/article/view/1861/0>. Acesso em: 20 mar. 2020.

MARTINS, Sandra. A experiência da modernidade e o patrimônio cultural. Reia Revista de Estudos e Investigações Antropológicas, Recife, vol. 1, n. 1, p. 7- 29, 2014. Disponível em: $\quad<$ https://periodicos.ufpe.br/revistas/reia/article/view/229950/24142> Acesso em: 20 ago. 2019.

NOGUEIRA, M. G. C.; NUNES, A. C. S. Restauração ou revitalização? Pontos para repensar o patrimônio público de Porto Velho. In: Simpósio Nacional de História, 27. Natal. Anais... Natal: UFRN, 2013. p. 1-14. Disponível em:

$<$ https://www.anpuh.org.br/index.php/documentos/anais/category-items/1-anais-simposiosanpuh/33-snh27 >. Acesso em: 20 fev. 2020.

NOS TRILHOS da Maria louca. Isto é. São Paulo, n. 2536, 02 fev. 2005. Disponível em: <https://istoe.com.br/98_NOS+TRILHOS+DA+MARIA+LOUCA/> Acesso em 12 mai. 2017.

PACHECO, Alexandre. Restauração, ruínas e experiência estética na estação da Estrada de Ferro Madeira Mamoré em Porto Velho (2007-2017). Patrimônio e História. Assis, v. 16, n. 1, 2020. Disponível em: <file://C:/Users/User/Downloads/1046-4223-1-

PB\%20(4).pdf>. Acesso em: 28 jul. 2020.

PINHEIRO, J. A.; SILVA, J. L. G. Estrada de Ferro Madeira Mamoré: abandono e destruição do patrimônio histórico e cultural. In: Encontro Latino Americano de Pósgraduação, 10., 2010, São José dos Campos, Anais eletrônicos..., São José dos Campos, UNIVAP, 2010.2 p. $1-6 . \quad$ Disponível em: $<$ http://www.inicepg.univap.br/cd/INIC_2010/anais/arquivos/0068_0090_01.pdf $>$. Acesso em: 12 jun. 2020. 
RAVANI, Andreia Silva Andrade. Arqueologia preventiva e os impactos sobre os bens arqueológicos no sítio Vila de Santo Antônio, área da Igrejinha, Porto Velho, RO. 2017. 78 f. Trabalho de Conclusão de Curso-Departamento de Arqueologia, Universidade Federal de Rondônia, Porto Velho, 2017. Disponível em: $<$ http://www.arqueologia.unir.br/uploads/03144268/TCC\%20ANDREIA\%20RAVANI\%2 02017.1.pdf $>$. Acesso em: 22 fev. 2020.

RESTAURAÇÃO do galpão da Madeira-Mamoré está na fase final. G1 RO, Porto Velho, 2 ago. 2013. Disponível em: http://g1.globo.com/ro/rondonia/noticia/2013/08/restauracao-do-galpao-da-madeiramamore-esta-na-fase-final-em-ro.html. Acesso em: 6 jun. 2020.

RODRIGUES, Angela Rosch. Ruína e patrimônio arquitetônico no Brasil: memória e esquecimento. V!rus, São Carlos, n. 16, p. 2018. Disponível em: $<$ http://www.nomads.usp.br/virus/virus16/secs/submitted/virus_16_submitted_3_pt.pdf >. Acesso em: 16 jul. 2019.

SANTOS, F. P.; ARAÚJO, R. C.; AGUIAR, S. G.; BARBA, C. H. Impactos sócioeconômicos das hidrelétricas do Madeira: um estudo no bairro Triângulo em Porto Velho/RO. In: Congresso Nacional de excelência em gestão, 10., Rio de Janeiro. Anais... Rio de Janeiro: UFF, 2014. p. 1-20. Disponível em: $<$ https://www.inovarse.org/sites/default/files/T14_0251_3.pdf >. Acesso em: 20 abr. 2020.

TEIXEIRA, Marco Antônio Domingues; FONSECA, Dante Ribeiro da. História Regional de Rondônia. Porto Velho, Rondoniana, 2003.

TRISTE FIM: peças abandonadas da Madeira Mamoré são vendidas como sucata.
Rondoniaovivo,
Porto
Velho,
2020
Disponível
$\mathrm{em}:<$

http://rondoniaovivo.com/geral/noticia/2020/01/25/triste-fim-pecas-abandonadas-damadeira-mamore-sao-vendidas-como-sucata.html> . Acesso em 30 mar. 2020. 